\title{
Gynura procumbens (Lour.) Merr. Leaves Against Mice's Antibody Titer
}

\author{
Rahimatul Uthia*1, Elin Resti Ananda ${ }^{2}$, Ifora ${ }^{2}$ \\ Poltekkes Kemenkes Riau', Sekolah Tinggi Ilmu Farmasi (STIFARM) Padang ${ }^{2}$ \\ *Email: rahimatul@pkr.ac.id
}

Article Info
Article history
Received date: 2019-11-05
Revised date: 2019-1 1-28
Accepted date: 2019-12-13

\begin{abstract}
The body's defense system can be enhanced by certain compounds that are immunostimulant. An antibody titer is a measure of the body's level of immunity to a disease. Titers are usually expressed in terms of the number of times they can thin the blood until they cannot find any more antibodies. This study aims to determine the activity of the extracts of the leaves of Gynura Procumbens (Lour.) Merr. against antibody titers, the number, and percentage of leukocyte cells of white male mice. 25 mice were divided into 5 groups consisting of negative control, positive control, group dose $75 \mathrm{mg} / \mathrm{kg}$ body weight, $150 \mathrm{mg} / \mathrm{kg}$ body weight, $300 \mathrm{mg} / \mathrm{kg}$ body weight. The extract is given for 7 days orally. The results showed that administration of leaf extracts can increase antibody titers and increase with increasing doses, as well as increasing the total number of leukocytes and the percentage of leukocyte cells significantly $(P<0.05)$.
\end{abstract}

Keywords:

Gynura Procumbens (Lour.) Merr.; Antibody titer; leukocyte cell

\section{Abstrak}

Sistem pertahanan tubuh dapat ditingkatkan dengan senyawa tertentu yang bersifat imunostimulan. Titer antibodi adalah pengukuran tingkat kekebalan tubuh terhadap suatu penyakit. Titer biasanya dinyatakan dalam rasio berapa kali bisa mengencerkan darah sampai tidak bisa menemukan antibodi lagi. Penelitian ini bertujuan untuk mengetahui aktivitas dari ekstrak daun sambung nyawa (Gynura Procumbens (Lour.) Merr.) terhadap titer antibodi, jumlah dan persentase sel leukosit mencit putih jantan. Hewan sebanyak 25 ekor dibagi atas 5 kelompok yang terdiri dari kontrol negatif, kontrol positif, kelompok dosis $75 \mathrm{mg} / \mathrm{kg} \mathrm{BB}, 150 \mathrm{mg} / \mathrm{kg} \mathrm{BB}, 300 \mathrm{mg} / \mathrm{kg} \mathrm{BB}$. Ekstrak diberikan selama 7 hari secara oral. Hasil penelitian menunjukkan pemberian ekstrak daun sambung nyawa dapat meningkatkan titer antibodi dan semakin meningkat dengan peningkatan dosis, serta meningkatkan jumlah total leukosit dan persentase sel leukosit secara signifikan $(P<0,05)$.

Kata Kunci

Titer antibody; daun sambung nyawa; sel leukosit.

\section{PENDAHULUAN}

Sistem imun adalah sistem pertahanan yang ada pada tubuh manusia yang berfungsi untuk menjaga manusia dari benda-benda asing bagi tubuh manusia. Pada sistem imun disebut dengan istilah imunitas. Imunitas sendiri adalah ketahanan tubuh kita atau resistensi tubuh kita terhadap suatu penyakit. Penyakit atau kuman ini berupa protein asing yang berbeda dari protein tubuh kita, dan sering disebut antigen. Antigen dianggap sesuatu yang asing, maka antigen ini harus disingkirkan, dinetralisir, atau dihancurkan [1].
Antibodi adalah bagian pertahanan tubuh yang digunakan untuk menghilangkan atau mengurangi zat asing yang masuk ke dalam tubuh. Mekanisme kerja antibodi dalam tubuh dimulai dengan diikatnya epitope (bagian antigen) oleh antibodi. Titer antibodi adalah pengukuran tingkat kekebalan tubuh terhadap suatu penyakit yang beredar dalam darah. Titer biasanya dinyatakan dalam rasio, yang berapa kali bisa mencairkan darah sampai tidak bisa menemukan antibodi lagi [2]. Mekanisme pertahanan tubuh dapat ditingkatkan dengan senyawa tertentu yang bersifat imunostimulan. Imunostimulan secara 
umum didefenisikan sebagai senyawa yang dapat meningkatkan mekanisme pertahanan tubuh baik secara spesifik maupun non spesifik baik mekanisme pertahanan seluler maupun humoral [3].

Daun sambung nyawa berkhasiat sebagai antipiretik dan anti bakteri [4], [5]. Ekstrak daun sambung nyawa memiliki khasiat sebagai antikanker [6], [7]. Penelitian sebelumnya juga menunjukan daun sambung nyawa (Gynura procumbens (Lour.) Merr.) pada dosis $75 \mathrm{mg} / \mathrm{kg} \mathrm{BB}$, dosis $150 \mathrm{mg} / \mathrm{kg} \mathrm{BB}$ dan dosis $300 \mathrm{mg} / \mathrm{kg}$ BB memiliki efek antiinflamasi dan mempengaruhi jumlah sel leukosit tikus putih jantan [8]. Kandungan senyawa aktif daun sambung nyawa yang memiliki khasiat antara lain alkaloid, minyak atsiri, flavonoid, polifenol, tannin, saponin, sterol tak jenuh, dan steroid [9], [10]

\section{METODE}

\section{Alat}

Alat yang digunakan adalah timbangan analitik (Precisa®), wadah maserasi, kain flanel, rotary evaporator (lka), gelas ukur (Pyrex $®)$, erlemeyer (Pyrex $®)$, gunting, tabung reaksi (Pyrex®), lumpang dan stamfer (Pyrex $\left.{ }^{\circledR}\right)$, kaca objek (Slides), pipet tetes, spatel, vial, pinset, kertas saring, botol timbang krus (Pyrex®), mikropipet (Eppendorf), rak tabung reaksi, blender (Miyako), plat tetes (Pyrex), timbangan hewan

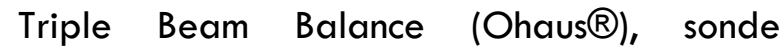
(Terumo®), mikroskop (Primo Star), plat KLT Sillica Gel 60 F254 (Merck), waterbath (Memmert), oven (Memmert), centrifuge, Lampu Sinar UV (Camag) dan hemocytometer (Qiujing).

\section{Bahan}

Daun Sambung nyawa (Gynura Procumbens (Lour.) Merr.), ekstrak etanol daun sambung nyawa, kloroform (Merck), aquadest (PT. Brataco), natrium klorida ( $\mathrm{NaCl}$ ) fisiologis $0,9 \%$ (PT. Widarta Bhakti), darah kambing, natrium karboksi metil selulosa (NaCMC) (PT. Brataco), etanol $70 \%$ (PT. Brataco), heparin (Fahrenheit), metanol (PT. Brataco), turk (Segara Husada Mandiri), minyak emersi, asam asetat (PT. Brataco), pewarna Giemsa (D6 100-Darmstadt).

\section{Cara Keria}

Pembuatan Ekstrak Eanol Daun Sambung Nyawa: Serbuk kering simplisia dimaserasi menggunakan pelarut yang sesuai (etanol 70 $\%$ ). Satu bagian serbuk simplisia kering dimasukan kedalam maserator, tambahkan 10 bagian pelarut, rendam selama 6 jam pertama sambil sekali-kali diaduk, kemudian diamkan selama 18 jam. Maserat dipisahkan dengan cara pengendapan, sentrifugasi, dekantasi, atau filtrasi. Ulangi proses penyarigan sekurang-kurangnya dua kali dengan jenis dan jumlah pelarut yang sama. Semua maserat dikumpulkan, kemudian di vapkan dengan vakum atau penguap tekanan rendah hingga diperoleh ekstrak kental. Setelah itu hitunglah rendemen yang diperoleh yaitu persentase bobot (b/b) antara rendemen dengan bobot serbuk simplisia yang digunakkan dengan penimbangan [1 11 ]. Persiapan Hewan Percobaan: Hewan yang digunakan adalah mencit putih jantan umur 23 bulan dengan berat antara 20-30 gram sebanyak 25 ekor, dikelompokkan secara acak menjadi 5 kelompok terdiri dari 5 ekor mencit. Sebelum diperlakukan mencit di aklimatisasi selama 7 hari dengan diberi makan dan minum yang cukup. Mencit yang akan digunakan adalah mencit yang sehat dan tidak menunjukan penurunan berat badan berarti (deviasi maksimal $10 \%$ ) serta secara visual menunjukan perlakuan yang normal [12].

Perencanaan Dosis: Dosis ekstrak daun sambung nyawa (Gynura procumbens (Lour.) Merr.) yang digunakan adalah $75 \mathrm{mg} / \mathrm{kg} \mathrm{BB}$, $150 \mathrm{mg} / \mathrm{kg} \mathrm{BB}$ dan $300 \mathrm{mg} / \mathrm{kg} \mathrm{BB}$.

Perlakuan Pada Hewan Percobaan: Hewan dibagi atas lima kelompok dengan masingmasing kelompok terdiri dari lima ekor, yaitu:

- Kelompok 1 yaitu kelompok mencit kontrol negatif hanya diberi larutan $\mathrm{NaCl}$ fisiologis.

- Kelompok II yaitu kelompok kontrol positif, mencit diimunisasi dengan eritrosit kambing dan pada hari ke 8 diberi larutan $\mathrm{NaCl}$ fisiologis 
- Kelompok III yaitu kelompok mencit yang diberikan suspensi ekstrak daun sambung nyawa (Gynura procumbens (Lour.) Merr.), dosis $75 \mathrm{mg} / \mathrm{kg} \mathrm{BB}$ secara oral 1 kali sehari selama 7 hari.

- Kelompok IV yaitu kelompok mencit yang diberikan suspensi ekstrak daun sambung nyawa (Gynura procumbens (Lour.) Merr.), dosis $150 \mathrm{mg} / \mathrm{kg} \mathrm{BB}$ secara oral 1 kali sehari selama 7 hari.

- Kelompok $\vee$ yaitu kelompok mencit yang diberikan suspensi ekstrak daun sambung nyawa (Gynura procumbens (Lour.) Merr.), dosis $300 \mathrm{mg} / \mathrm{kg} \mathrm{BB}$ secara oral 1 kali sehari selama 7 hari.

Pembuatan Larutan Uji: Suspensi $\mathrm{Na}$ CMC 0,5\% dibuat dengan cara $\mathrm{Na}$ CMC ditimbang $500 \mathrm{mg}$ dikembangkan dengan air panas 20 kalinya, setelah mengembang digerus kemudian ditambahkan ekstrak etanol daun sambung nyawa (Gynura procumbens (Lour.) Merr.) sesuai konsentrasi ekstrak yang telah direncanakan, kemudian digerus homogen dan dicukupkan dengan aquadest sampai volume $100 \mathrm{~mL}$. Konsentrasi ekstrak daun sambung nyawa (Gynura procumbens (Lour.) Merr.) yang dibuat adalah $0,75 \% ; 1,5$ $\%$; dan $3 \%$.

Pembuatan Larutan Antigen: Darah kambing diambil dan dicuci dengan $\mathrm{NaCl}$ fisiologis (1:1) masing-masing sebanyak $5 \mathrm{~mL}$ aduk homogen. Kemudian disentrifus dengan kecepatan 2000 rpm selama 15 menit, buang supernatannya, ulangi 3 kali dengan menambahkan $\mathrm{NaCl}$ fisiologis setiap pengulangan. Setelah didapatkan eritrosit kambing, kemudian buat suspensi $5 \%$, caranya ambil $0,2 \mathrm{~mL}$ eritrosit kambing lalu tambahkan dengan $\mathrm{NaCl}$ fisiologis hingga volume $4 \mathrm{ml}$.

Sensitisasi Hewan: Mencit diberi imunogen dengan $0,2 \mathrm{~mL}$ suspensi eritrosit kambing $5 \%$ pada hari pertama setelah aklimatisasi secara intra peritoneal, kemudian lakukan pembosteran dengan $0,1 \mathrm{~mL}$ suspensi eritrosit kambing $5 \%$ secara subcutan pada hari ke 7 . Suspensi dari ekstrak diberikan pada hari ke
8 sampai hari ke 14 secara oral dengan dosis $75,150,300 \mathrm{mg} / \mathrm{kg} \mathrm{BB}$.

Titer Antibodi: Pada hari ke-15 mencit dikorbankan, diambil darah dari vena leher, biarkan selama 30 menit, lalu disentrifus dengan kecepatan $2000 \mathrm{rpm}$ selama 15 menit ambil bagian serumnya. Untuk serum dari satu ekor mencit disiapkan 10 tabung reaksi yang telah berisi larutan $\mathrm{NaCl}$ fisiologis $0,2 \mathrm{~mL}$. Pada tabung pertama ditambahkan 0,2 $\mathrm{mL}$ serum, kocok sampai homogen. Pindahkan 0,2 $\mathrm{mL}$ larutan tabung pertama kedalam tabung kedua kemudian kocok dan pipet $0,2 \mathrm{~mL}$ larutan tabung kedua, pindahkan kedalam tabung ketiga. Lakukan ini sampai tabung tabung kesepuluh, pada tabung kesepuluh buang $0,2 \mathrm{~mL}$. Sehingga hasil pengenceran dari serum yaitu $1 / 2,1 / 4,1 / 8,1 / 16,1 / 32$, $1 / 64,1 / 128,1 / 256,1 / 512,1 / 1024$. Masukkan $0,1 \mathrm{~mL}$ suspensi eritrosit kambing 5 $\%$ kedalam masing-masing tabung reaksi tersebut lalu diamkan selama 10 menit. Sentrifus selama 5 menit dengan kecepatan 2000 rpm, amati gumpalan yang terjadi. Angka titer ditentukan dengan pengenceran tertinggi dari serum mencit yang masih mengalami aglutinasi dengan eritrosit kambing.

Perhitungan Jumlah Sel Leukosit: Darah segar yang telah diberi heparin dihisap dengan pipet thoma leukosit sampai angka 0,5 tambahkan larutan Turk sampai angka 11 selanjutnya dikocok selama 3 menit. Larutan dari dalam pipet 1-2 tetes pertama dibuang dan diteteskan satu tetes pada kamar hitung. Cairan dialirkan selama 2 menit agar leukosit mengendap. Jumlah sel darah putih dihitung pada 4 kotak besar dan 64 kotak sedang pada kamar hitung Hemocytometer.

Perhitungan Presentase Sel Leukosit: Darah segar diteteskan pada gelas objek (1 tetes), tipiskan, dan ratakan dengan gelas objek lain, sehingga diperoleh lapisan darah yang homogen (hapusan darah), lalu keringkan. Setelah kering ditetesi dengan metanol sehingga menutupi seluruh hapusan darah, biarkan 5 menit. Tambahkan satu tetes Giemsa yang telah diencerkan dalam aquadest (1:20), biarkan selama 20 menit. Cuci dengan aquadest, setelah kering lihat 
dibawah mikroskop. Hitung jumlah sel eusionofil, netrofil batang, netrofil segmen, limfosit, dan monosit pada perbesaran 1000x dengan menggunakan minyak emersi.

Analisa Data: Data hasil penelitian diolah dengan statistik menggunkan uji ANOVA satu arah dan dilanjutkan dengan uji Duncan.

\section{HASIL DAN PEMBAHASAN}

Setelah dilakukan penelitian tentang uji aktivitas ekstrak etanol daun sambung nyawa (Gynura procumbens (Lour.) Merr.) terhadap titer antibodi, jumlah dan persentase sel leukosit mencit putih jantan diperoleh hasil sebagai berikut:

Hasil pengamatan organoleptis menunjukan bahwa ekstrak berwarna coklat, rasa agak pahit, baunya khas, dan konsistensi berupa ekstrak kental. Dari maserasi sebanyak 298,9 g serbuk kering daun sambung nyawa (Gynura Procumbens (Lour.) Merr.) dengan etanol $70 \%$ didapat ekstrak kental sebanyak 36,04 g dengan rendemen 12,06\%.

Berdasarkan hasil uji susut pengeringan dari ekstrak diperoleh 7,58\%. Ekstrak daun sambung nyawa juga positif bereaksi dengan pereaksi alkaloid, saponin, tanin, flavonoid, steroid dan terpenoid.

Pengamatan aktivitas titer antibodi jumlah dan persentase sel leukosit setelah pemberian ekstrak etanol daun sambung nyawa selama 7 hari dan diimunisasi eritrosit kambing sebagai antigen:

1. Hasil penentuan titer antibodi dari serum mencit putih jantan setelah diinduksi dengan eritrosit kambing $5 \%$ dan pemberian ekstrak daun sambung nyawa (Gynura procumbens (Lour.) Merr.) pada dosis $75 \mathrm{mg} / \mathrm{kg} \mathrm{BB}, 150 \mathrm{mg} / \mathrm{kg} \mathrm{BB}, 300$ $\mathrm{mg} / \mathrm{kg} B B$ secara berurutan adalah: 4,0 ; 5,4 ; dan 6,2. Untuk kontrol negatif dan kontrol positif adalah 1,8 dan 3,6 .

2. Hasil perhitungan jumlah total sel leukosit darah mencit putih jantan setelah diinduksi dengan eritrosit kambing $5 \%$ dan pemberian ekstrak daun sambung nyawa (Gynura procumbens (Lour.) Merr.) pada dosis $75 \mathrm{mg} / \mathrm{kg} \mathrm{BB}, 150 \mathrm{mg} / \mathrm{kg} \mathrm{BB}, 300$ $\mathrm{mg} / \mathrm{kg} \quad B B$ secara berurutan adalah: 15.810; 16.960; 18.240. Untuk kontrol negatif dan kontrol positif adalah 14.050 dan 15.580 .

3. Hasil perhitungan persentase sel leukosit darah mencit putih jantan setelah diinduksi dengan eritrosit kambing $5 \%$ dan pemberian ekstrak daun sambung nyawa (Gynura procumbens (Lour.) Merr.) untuk sel eusinofil, neutrofil batang, neutrofil segmen, limfosit dan monosit secara berurutan adalah: pada dosis $75 \mathrm{mg} / \mathrm{kg} \mathrm{BB} \mathrm{4,2;8,6;}$ 19,$8 ; 57,6 ; 9,8$ pada dosis $150 \mathrm{mg} / \mathrm{kg} \mathrm{BB}$ 5,2; 9,2; $\quad 15,8 ; \quad 58,8 ; \quad 11$ pada dosis $300 \mathrm{mg} / \mathrm{kg} \mathrm{BB}, 5,6 ; 10,4 ; 11,4$ $; 60,2 ; 12,4$. Untuk kontrol negatif 2,$0 ; 7,0$ ; 28,02; 55,0; 7,8 dan kontrol positif adalah 3,$6 ; 7,8 ; 23,2 ; 56,4 ; 9,0$.

Hasil pengamatan terhadap uji aktivitas ekstrak daun sambung nyawa (Gynura Procumbens (Lour.) Merr.) terhadap titer antibodi, jumlah dan persentase sel leukosit mencit putih jantan dengan perlakuan ekstrak etanol daun sambung nyawa dengan variasi dosis telah dilakukan uji analisis statistik yang dapat dilihat pada gambar 1, 2 dan gambar 3.

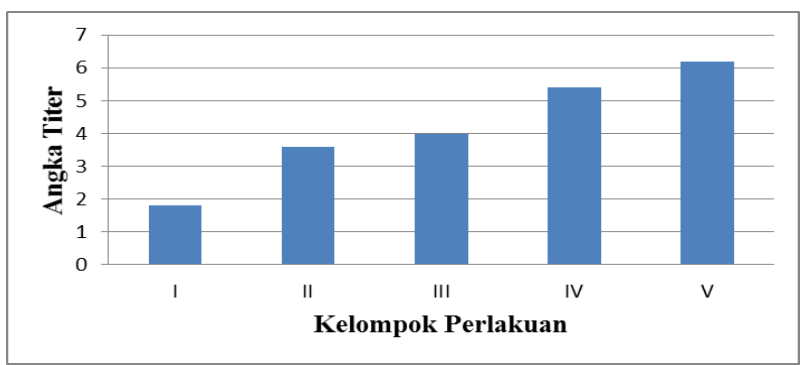

Gambar 1. Diagram batang angka titer antibodi terhadap kelompok perlakuan setelah diinduksi dengan eritrosit kambing $5 \%$ dan pemberian ekstrak daun sambung nyawa (Gynura procumbens (Lour.) Merr.) 


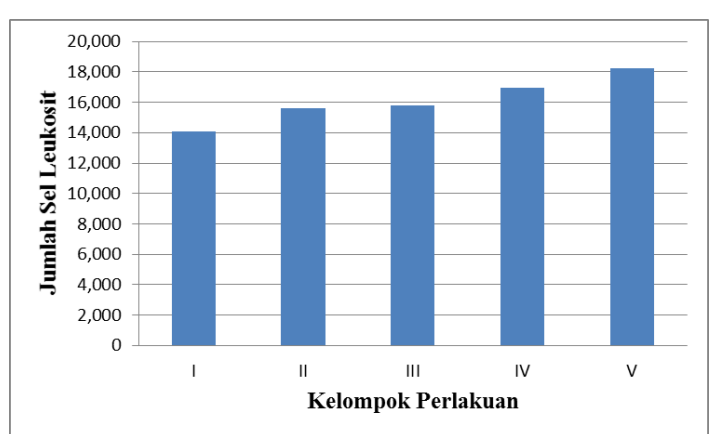

Gambar 2. Diagram batang jumlah sel leukosit terhadap kelompok perlakuan setelah diinduksi dengan eritrosit kambing $5 \%$ dan pemberian ekstrak daun sambung nyawa (Gynura procumbens (Lour.) Merr.)

Gambar 3. Diagram batang persentase sel leukosit terhadap kelompok perlakuan setelah diinduksi dengan eritrosit kambing $5 \%$ dan pemberian ekstrak daun sambung nyawa (Gynura procumbens (Lour.) Merr.)

Keterangan :

I : Kelompok kontrol negatif

II : Kelompok kontrol positif

III : Dosis $75 \mathrm{mg} / \mathrm{kg} \mathrm{BB}$

IV : Dosis $150 \mathrm{mg} / \mathrm{kg} \mathrm{BB}$

$V$ : Dosis $300 \mathrm{mg} / \mathrm{kg} \mathrm{BB}$

Mencit dibagi menjadi lima kelompok, masing-masing kelompok terdiri dari lima ekor mencit putih jantan. Kelompok pertama adalah kelompok kontrol negatif yang hanya diberi $\mathrm{NaCl}$ fisiologis, kelompok kedua adalah kelompok kontrol positif yang diimunisasi dengan eritrosit kambing dan pada hari ke 8 diberi larutan $\mathrm{NaCl}$ fisiologis, sedangkan tiga kelompok lainnya adalah tiga variasi dosis yang berbeda yaitu $75 \mathrm{mg} / \mathrm{kg} \mathrm{BB}, 150 \mathrm{mg} / \mathrm{kg} \mathrm{BB}$, dan 300 $\mathrm{mg} / \mathrm{kg} \mathrm{BB}$.

Penentuan angka titer antibodi dengan metoda hemaaglutinasi. Dasar pemilihan metoda ini selain murah, waktu yang dibutuhkan untuk mengetahui angka titer relatif singkat. Angka titer ditentukan pada pengenceran tertinggi dari serum mencit yang masih dapat beraglutinasi dengan sel darah merah kambing, angka titer dapat dicari dengan rumus 2 log pengenceran. Pada kelompok kontrol negatif aglutinasi masih terlihat jelas pada $2 \log 2$ maka angka titernya adalah 1, aglutinasi yang terjadi dipengaruhi oleh komplemen, komplemen yaitu salah satu enzim serum yang berasal dari sistem imun non spesifik larut dalam keadaan tidak aktif, tapi setiap waktu dapat diaktifkan oleh berbagai bahan seperti antigen, kompleks imun dan sebagainya. Sedangkan pada kontrol positif aglutinasi terjadi pada $2 \log 16$ maka angka titernya adalah 4 antigen yang digunakan eritrosit kambing $5 \%$ yang diinjeksikan pertama kali secara intra peritonial dengan tujuan agar terbentuk antibodi spesifik terhadap antigen tersebut pada pemaparan berikutnya. Pada hari ke 7 dilakukan pembosteran dengan antigen secara subkutan, sehingga terjadi sensitisasi dari sistem imun.

Pemilihan eritrosit kambing $5 \%$ sebagai antigen terbukti dapat meningkatkan jumlah antibodi dari serum mencit. Setelah pemberian ekstrak etanol daun sambung 
nyawa dengan dosis $75 \mathrm{mg} / \mathrm{kg} \mathrm{BB}, 150$ $\mathrm{mg} / \mathrm{kg} \quad B B, \quad 300 \mathrm{mg} / \mathrm{kg} \quad B B$ terjadi peningkatan angka titer yaitu 4,$0 ; 5,4$; dan 6,2 . Data hasil perhitungan titer antibodi dengan anova satu arah menunjukkan bahwa dengan pemberian antigen eritrosit kambing $5 \%$ dan ekstrak daun sambung nyawa dapat meningkatkan produksi antibodi $(P<0,05)$ dan berdasarkan angka titer yang didapatkan cenderung tinggi. Peningkatan angka titer yang sejalan dengan peningkatan dosis, menunjukkan ekstrak daun sambung nyawa memiliki kemampuan sebagai imunostimulan karena dapat meningkatkan produksi antibodi. Analisa dengan uji lanjut Duncan menunjukkan pemberian ekstrak daun sambung nyawa pada dosis $300 \mathrm{mg} / \mathrm{kg}$ memberikan efek yang lebih baik terhadap peningkatan angka titer antibodinya.

Selain itu juga dilakukan uji jumlah total leukosit menggunakan alat haemocytometer. Data hasil perhitungan jumlah total leukosit diolah dengan anova satu arah didapatkan hasil yang signifikan $(P<0,05)$ berarti bahwa pemberian ekstrak daun sambung nyawa dapat meningkatkan jumlah total sel leukosit. Analisa dengan uji lanjut Duncan menunjukkan pemberian ekstrak daun sambung nyawa pada dosis $300 \mathrm{mg} / \mathrm{kg}$ memberikan efek yang lebih baik terhadap peningkatan jumlah sel leukositnya.

Pada pemeriksaan hapuan darah, dilakukan perhitungan persetase jenis sel leukosit yaitu sel eusinofil, sel neutrofil batang, sel neutrofil segmen, limfosit dan monosit setelah dilakukan pewarnaan dengan giemsa. Pada pewarnaan giemsa ini basofil tidak ditemukan kerena sel basofil bersifat basa sehingga sel tersebut larut dalam pewarna giemsa [13], [14]. Dari hasil uji statistik analisa varian satu arah dilihat dari tabel homogen variabel data sel eusinofil, sel neutrofil batang, sel neutrofil segmen, limfosit dan monosit menunjukkan hasil yang homogeny $(P>0,05)$ sehingga dapat diteruskan dengan uji anova satu arah. Pada hasil hitungan anova menunjukkan pemberian ekstrak daun sambung nyawa berpengaruh terhadap angka rata-rata persentase leukosit $(P<0,05)$.
Analisa statistik dilanjutkan dengan uji lanjut Duncan menunjukkan pemberian ekstrak daun sambung nyawa pada dosis 300 $\mathrm{mg} / \mathrm{kg}$ memberikan efek yang lebih baik terhadap peningkatan jumlah sel eusinofil, neutrofil, neutrofil segmen, limfosit, dan monositnya.

Eusinofil berfungsi melawan infeksi parasit dan juga melawan kompleks antigen antibody [15]. Neutrofil merupakan sel yang pertama yang dikerahkan ketempat bakteri masuk dan berkembang dalam tubuh. Monosit berfungsi mengenal, menyerang mikroba dan sel kanker, memproduksi sitokin dan mengerahkan pertahanan sebagai respon terhadap infeksi [16]. Peningkatan jumlah sel limfosit ini berarti terjadi peningkatan pada respon imun spesifik. Sel limfosit terdiri dari sel limfosit $B$ dan sel limfosit T. Sel limfosit B akan mengalami proliferasi dan diferensiasi membentuk sel plasma dan sel memori. Sel plasma inilah yang membentuk antibodi yang terbentuk setelah kontak dengan antigen. Untuk membentuk antibodi, sel plasma perlu melakukan kerja sama dengan sel limfosit $T$ [17], [18].

\section{SIMPULAN}

Berdasarkan penelitian yang telah dilakukan tentang Uji Aktivitas Ekstrak Etanol Daun Sambung Nyawa (Gynura procumbens (Lour.) Merr.) tehadap Titer Antibodi, Jumlah Dan Persentase Sel Leukosit Mencit Putih Jantan, maka dapat disimpulkan bahwa pemberian ekstrak daun sambung nyawa (Gynura procumbens (Lour.) Merr.) selama 7 hari dapat meningkatkan titer antibodi, meningkatkan jumlah total sel leukosit dan dapat meningkatkan persentase sel leukosit mencit putih jantan.

\section{DAFTAR PUSTAKA}

[1] P. D. Hasdianah, Peristowati, S. Imam, Imunologi diagnosa dan teknik biologi molekuler, Edisi 1, Yogyakarta: Nuha Medika, 2014.

[2] S. Emantoko, "Antibodi rekombinan: perkembangan terbaru dalam 
teknologi antibody," Jurnal Unitas. 9, 2, 29-43, 2001.

[3] S. B. Kresno, Imunologi Diagnosis dan Prosedur Laboratorium, Edisi IV, Jakarta: Fakultas Kedokteran Universitas Indonesia, 2001.

[4] D. N. Nuraini, Aneka daun berkhasiat untuk tanaman obat. Yogyakarta: Gava Media, 2014.

[5] B. Mahendra, 13 Jenis Tanaman Obat Ampuh, Jakarta: Penebar Swadaya, 2005.

[6] I. P. Sari \& N. Yuniarti, "Efek estrogenik dari ekstrak etanol daun sambung nyawa (Gynura procumbens (Lour.) Merr.) pada tikus," Majalah Farmasi Indonesia, 5, 4, 158-162, 2004.

[7] M. Y. Fadli, "Benefits of sambung nyawa (Gynura procumbens) substance as anticancer", Medical Journal of Lampung University, 4(5), 50-53, 2015.

[8] R. Uthia, W. Kardela dan K. B. Transida, "Uji efek antiinflamasi ekstrak etanol daun sambung nyawa (Gynura procumbens (Lour.) Merr.) terhadap kaki tikus putih jantan," Jurnal Farmasi Higea, 10, 1, 25-32, 2018.

[9] P. Utami dan D. E. Puspaningtyas, "The Miracle of Herbs," Jakarta: AgroMedia Pustaka, 2013.

[10] N. Kaewseejan, V. Sutthikhum, \& S. Siriamornpun, "Potential of gynura procumbens leaves as source of flavonoid enriched fractions with enhanced antioxidant capacity,"
Journal of functional foods, 12, 5, 120$128,2015$.

$\begin{array}{llr}\text { [11] } & \begin{array}{l}\text { Kementrian } \\ \text { Indonesia, }\end{array} \text { Kesehatan } & \text { Republik } \\ \text { Indonesia, Edisi 1, } & \text { Jakarta: } \\ \text { Departemen Kesehatan } & \text { Republik } \\ \text { Indonesia, 2010. } & \end{array}$

[12] H. Vogel, Drug discovery and evaluations pharmacological assays, $2^{\text {th }}$ Edition, Germany: Springer-Verlag Berlin Heidelberg, 2002.

[13] Y. Aldi, N. Ogiana dan D. Handayani, "Uji Imunomodulator Beberapa Subfra ksi Ekstrak Etil AsetatMeniran (Phyllant hus niruri L.) pada Mencit Putih Jantan dengan Metoda Carbon Clearance," dalam Prosiding Seminar Nasional Perkembangan Terkini Sains Farmasi dan Klinik III, 2013, 134-147

[14] Y. Aldi, Mahyudin dan D. Handayani, "Uji aktivitas beberapa subfraksi ekstrak etil asetat dari herba meniran (phyllanthus niruri Linn.) terhadap reaksi hipersensitivitas kutan aktif," Jurnal Sains dan Farmasi, 18, 1, 9-16, 2013.

[15] K. G. Baratawidjaja. Imunologi dasar, Edisi VIII, Jakarta: Penerbit Universitas Indonesia. 2009.

[16] T. J. Kindt, R. A. Goldsby, B. A. Osborn, Kuby Imunnology, New York: WH Freeman and Company, 2007.

[17] G. Pinchuk, Immunology, New York USA: The Mecgraw Hill Companies, 2002.

[18] M. Radji, Imunologi dan Virologi, Edisi 2, Jakarta Barat: PT. ISFI Penerbitan, 2015. 